\title{
EFFICACY OFPLATELET RICH PLASMA VERSUS AUTOLOGOUS EMULSIFIED FAT IN THE TREATMENT OF INFRAORBITAL DARK CIRCLES
}

\author{
By
}

\section{Ahmed Kadry Nabih Attia, Abd El-Raouf Mohammed Al-Mohsen and Shady Mahmoud Attia}

Department of Dermatology, Venereology and Andrology, Faculty of Medicine, Al-Azhar University

Corresponding Author: Ahmed Kadry Nabih,

Mobile: +201003262529, E-mail: ahmedkadry420@gmail.com

\begin{abstract}
Background: Periorbital hyperpigmentation, generally called dark circles, is a condition characterized by relatively dark coloration of the periorbital eyelids. It is a common worldwide problem which makes a person appear tired, sad, and aged. Although this condition does not cause physical morbidity, it can pose a substantial cosmetic problem and, eventually, affect the quality of the effected individual.

Objective: To evaluate the efficacy of platelet rich plasma versus autologous emulsified fat in the treatment of infraorbital dark circle.

Patients and methods: Our study was carried out on 30 patients presenting with infraorbital dark circles of different etiological factors divided into A and B from December 2019 to July 2020.All patients were recruited from the Dermatology outpatient clinic of Al-Azhar University Hospitals. Patients were divided into two equal groups: Group A treated with platelet rich plasma (PRP) and Group B treated by autologous fat injection.

Results: The present study showed excellent response of 3 patients (20\%) in group A, and 7 patients (46.7\%) in group B. Moderate response occurred in 2 patients (13.3\%) in group A, and 4 patients (26.7\%) in group B. Mild response occurred in 2 patients (13.3\%) in group A, and 3 patients (20\%) in group B. No response occurred in 8 patients $(53.3 \%)$ in group $\mathrm{A}$ and 1 patient (6.7\%) in group B.

Conclusion: Both PRP and emulsified fat were effective in treatment of infraorbital dark circles with statistically significant difference as regard the improvement, patient satisfaction and postoperative complications at the end of treatment period and follow up for six months.
\end{abstract}

Keywords: Platelet Rich Plasma, Autologous Fat, Infraorbital Dark Circles.

\section{INTRODUCTION}

Periorbital hyperpigmentation seems to have multifactorial causes that involve intrinsic factors (determined by the individual's genetics), and extrinsic factors (sun exposure, smoking, alcoholism and sleep disturbance. However, the presence of melanin pigment and hemosiderin pigment in the affected sites is a distinctive feature in its aetiopathogenesis (Taskin, 2015). The extent of the problem is reflected in many products advertised to either lighten or cover the pigmentation (Alsaad and Mikhail, 2013).

Another common cause of infraorbital dark circles can be thin, translucent lower 
eyelid skin overlying the orbicularis oculi muscle. The orbicularis oculi muscle lies right beneath the skin, with little or no subcutaneous fat, and the darkness may be due to the visible prominence of the subcutaneous vascular plexus or vasculature contained within the muscle. This condition usually involves the entire lower eyelids, with a violaceous appearance consistent with prominent blood vessels covered by a thin layer of skin. The violaceous appearance is more prominent in the inner aspect of the lower eyelids and is usually accentuated during menstruation (Ranu et al., 2011). Possible causative factors of the dark circles include genetic or hereditary, excessive pigmentation, periorbital edema, excessive vascularity, and shadowing due to skin laxity and tear trough (Robers, 2014).

The initial popularity of PRP grew from its promise as a safe and natural alternative to surgery. PRP advocates promoted the procedure as an organically based therapy that enabled healing through the use of one's own natural growth factors. In recent years, scientific research and technology has provided a new perspective on platelets. Studies suggest that platelets contain an abundance of growth factors and cytokines that can affect inflammation, postoperative blood loss, infection, osteogenesis, wound, muscle tear and soft tissue healing (Anitua et al., 2012).

Autologous fat grafting has become quite popular in tissue reconstruction and augmentation over the past decade. Its regenerative properties and beneficial effects with respect to skin texture have been observed in several studies.
Hyperpigmentation, skin texture, and scar quality may equally play an important role in determining a suitable treatment and resulting outcome. Consequently, described a new technique introducing Nano fat and hypothesized that it could be applied in various other skin conditions such as wrinkles and discolorations. Wrinkles and skin discolorations are usually addressed with expensive dermatological treatments such as "fillers" and erosive chemical peelings that require numerous sessions. Such treatments often have no permanent effect. Therefore, wrinkles and discolorations might also benefit from the long-term regenerative properties of Nano fat (Uyulmazet al., 2018).

The present work aimed to evaluate the efficacy of platelet rich plasma versus autologous emulsified fat in the treatment of infraorbital dark circle.

\section{PATIENTS AND METHODS}

This study was carried out on 30 patients presenting with infraorbital dark circles of different etiological factors from December 2019 to July 2020.Patients were randomized into two equal groups: Group A treated with platelet rich plasma, and Group B treated with autologous fat injection. All patients were recruited from the Dermatology outpatient clinic of Al-Azhar University Hospitals.

\section{Response to treatment:}

i. Excellent response: Complete resolution of dark halos like the surrounding skin.

ii. Moderate response: Improved color but still not like the surrounding skin. 
iii. Mild response: improved color but still close to the preoperative picture.

iv. No response: same color of the dark halos as preoperative picture.

Follow-up of patients was done every one month for six months to detect improvement. The side effects of treatment were recorded such as ecchymosis and brusis.

All patients were subjected to complete medical history, dermatological examination and documented digital photography.

\section{Statistical analysis:}

Results of the present study were statistically analyzed using SPSS 25 (IBM, USA). Data were represented as median \pm SD or number and percentage. Numerical data were compared using Mann-Whitney U test, while categorical data were compared using Chi-square test as appropriate.P value $<0.05$ was considered significant.

\section{RESULTS}

Regarding demographic data, there was no statistically significant difference between both groups regarding age, sex, skin type and family history (Table1).

Table (1): Comparison between studied groups as regard demographic data

\begin{tabular}{|c|c|c|c|c|c|c|}
\hline \multicolumn{2}{|c|}{$\begin{array}{ll}\text { Demographicdata } & \text { Groups } \\
\end{array}$} & \multirow{2}{*}{\multicolumn{2}{|c|}{$\begin{array}{c}\begin{array}{c}\text { Group A } \\
(\mathbf{N}=\mathbf{1 5})\end{array} \\
31.6 \pm \mathbf{6 . 7}\end{array}$}} & \multirow{2}{*}{\multicolumn{2}{|c|}{$\begin{array}{c}\begin{array}{c}\text { Group B } \\
(\mathbf{N}=\mathbf{1 5})\end{array} \\
32.3 \pm \mathbf{1 0 . 6} \\
\end{array}$}} & \multirow{2}{*}{$\begin{array}{c}\text { P-value } \\
0.823\end{array}$} \\
\hline Age (years) & Mean \pm SD & & & & & \\
\hline \multirow{2}{*}{ Sex } & Male & 2 & $13.3 \%$ & 2 & $13.3 \%$ & \multirow{2}{*}{1.0} \\
\hline & Female & 13 & $86.7 \%$ & 13 & $86.7 \%$ & \\
\hline \multirow{2}{*}{ Skin type } & III & 12 & $80 \%$ & 7 & $46.7 \%$ & \multirow{2}{*}{0.058} \\
\hline & IV & 3 & $20 \%$ & 8 & $53.3 \%$ & \\
\hline \multirow{2}{*}{$\begin{array}{l}\text { Family } \\
\text { history }\end{array}$} & Negative & 9 & $60 \%$ & 8 & $53.3 \%$ & \multirow{2}{*}{0.713} \\
\hline & Positive & 6 & $40 \%$ & 7 & $46.7 \%$ & \\
\hline
\end{tabular}

There was a statistically significant difference ( $\mathrm{p}$-value $<0.05$ ) between studied groups as regard improvement as the present study showed excellent response of 3 patients $(20 \%)$ in group A and 7 patients $(46.7 \%)$ in group B. Moderate response occurred in 2 patients $(13.3 \%)$ in group A and 4 patients $(26.7 \%)$ in group B. Mild response of 2 patients (13.3\%) in group A and 3 patients $(20 \%)$ in group B. No response occurred in 8 patients $(53.3 \%)$ in group $\mathrm{A}$ and 1 patient $(6.7 \%)$ in group B. There was a statistically significant difference ( $p$-value $<0.05$ ) between studied groups as regard patient satisfaction. There was a highly satisfaction of 3 patients (20\%) in group A and 10 patients $(66.7 \%)$ in group $B$. satisfaction occurred in 8 patients $(53.3 \%)$ in group $\mathrm{A}$ and 4 patients $(26.7 \%)$ in group B, no satisfaction in 4 patients $(26.7 \%)$ in group A and one patient $(6.7 \%)$ in group B (Table 2). 
Table (2): Comparison between studied groups as regard improvement and patient satisfaction

\begin{tabular}{|c|c|c|c|c|c|c|}
\hline \multirow{2}{*}{ Parameters } & Groups & \multicolumn{2}{c|}{$\begin{array}{c}\text { Group A } \\
\text { (N= 15) }\end{array}$} & \multicolumn{2}{c|}{$\begin{array}{c}\text { Group B } \\
(\mathbf{N = 1 5})\end{array}$} & \multirow{2}{*}{ P-value } \\
\hline \multirow{4}{*}{ Improvement } & No & 8 & $53.3 \%$ & 1 & $6.7 \%$ & \multirow{3}{*}{} \\
\cline { 2 - 6 } & Mild & 2 & $13.3 \%$ & 3 & $20 \%$ & \multirow{2}{*}{$\mathbf{0 . 0 4 8}$} \\
\cline { 2 - 6 } & Moderate & 2 & $13.3 \%$ & 4 & $26.7 \%$ & \\
\cline { 2 - 6 } & Excellent & 3 & $20 \%$ & 7 & $46.7 \%$ & \\
\hline \multirow{3}{*}{$\begin{array}{c}\text { Patients } \\
\text { satisfaction }\end{array}$} & Not satisfied & 4 & $26.7 \%$ & 1 & $6.7 \%$ & \multirow{2}{*}{$\mathbf{0 . 0 3 2}$} \\
\cline { 2 - 6 } & Satisfied & 8 & $53.3 \%$ & 4 & $26.7 \%$ & \\
\cline { 2 - 6 } & Highly satisfied & 3 & $20 \%$ & 10 & $66.7 \%$ & \\
\hline
\end{tabular}

There was a statistically significant studied groups as regard postoperative difference $(\mathrm{p}$-value $<0.05)$ between ecchymosis and bruises (Table 3).

Table (3): Comparison between studied groups as regard postoperative ecchymosis and bruises

\begin{tabular}{|c|c|c|c|c|c|c|}
\hline \multirow{2}{*}{ Side effects } & Groups & \multicolumn{2}{|c|}{$\begin{array}{c}\text { Group A } \\
(\mathbf{N = 1 5})\end{array}$} & \multicolumn{2}{|c|}{$\begin{array}{c}\text { Group B } \\
(\mathbf{N}=15)\end{array}$} & \multirow{2}{*}{ P-value } \\
\hline $\begin{array}{c}\text { Postoperative } \\
\text { ecchymosis and bruises }\end{array}$ & Minimal & 6 & $40 \%$ & 12 & $80 \%$ & \multirow{2}{*}{$\mathbf{0 . 0 2 5}$} \\
\cline { 2 - 7 } & Mild & 9 & $60 \%$ & 3 & $20 \%$ & \\
\hline
\end{tabular}

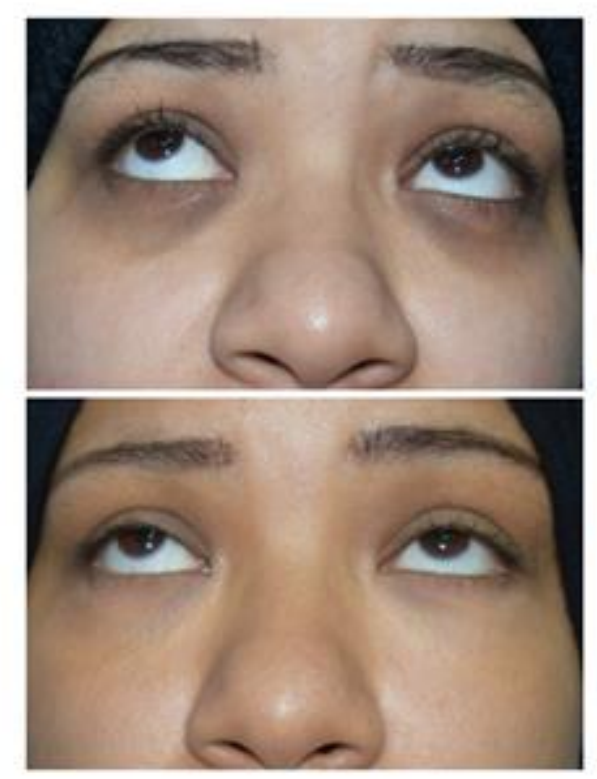

Figure (1): A 42 years old female with dark halos before and after treatment with emulsified fat showing excellent improvement
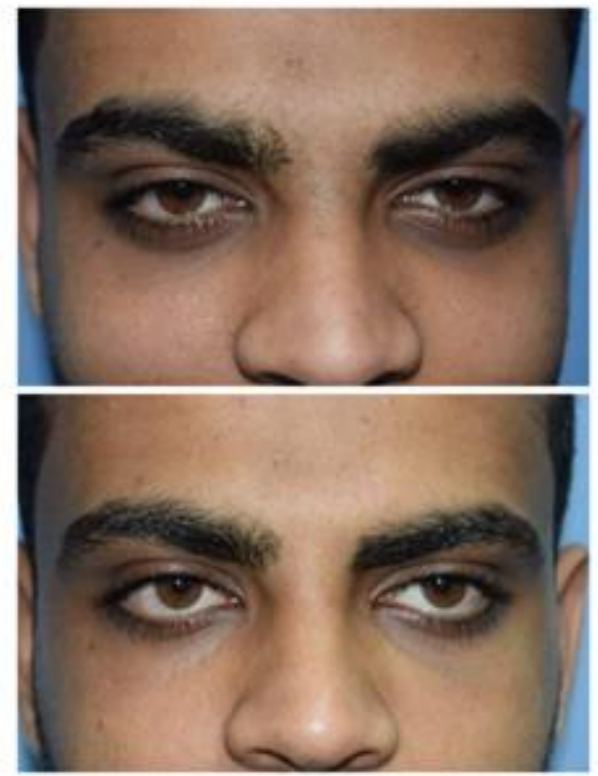

Figure (2): A 25 years old male with dark halos before and after treatment with PRP showing excellent improvement 


\section{DISCUSSION}

In this study, there were no significant difference between both groups regarding age, sex, family history, and skin type. The present study showed excellent response of 3 patients (20\%) in group A and 7 patients $(46.7 \%)$ in group B. Moderate response occurred in 2 patients $(13.3 \%)$ in group A and 4 patients $(26.7 \%)$ in group B. Mild response of 2 patients $(13.3 \%)$ in group $\mathrm{A}$ and 3 patients (20\%) in group B. No response occurred in 8 patients $(53.3 \%)$ in group $A$ and 1 patient $(6.7 \%)$ in group B. The reported side effects were mild ecchymosis and bruises which is less likely to occur in fat injection.

In agreement with this study, Zzam et al. (2020) concluded that autologous fat transplantation is an effective method for the treatment of infraorbital dark circles due to thin and translucent lower eyelid skin overlying the orbicularis oculi muscle. Also, there was significant clinical improvement of the periocular dark halos in $50 \%$, moderate improvement was encountered in $20 \%$, mild improvement was encountered in $20 \%$, and no change in the color was noted in $10 \%$. There was good agreement about the clinical outcome between the two evaluating surgeons who were blind to the used technique. In this study, despite the wide range of objective improvement (no improvement, mild, moderate and significant), $80 \%$ were satisfied with the final result and $20 \%$ were not satisfied and that was agreement with our study.

Oh et al. (2014) reported that patients who were unhappy with soft tissue filler injection to the periorbital area tended to have thinner skin, which is more vulnerable to developing increased vascularity, bruising, or contour irregularities. This is why fat grafting, which is readily available, safe, and completely biocompatible, is preferred to soft tissue fillers for dark circles accompanying thin eyelid skin.

Al Shami (2014), Mehryan et al. (2014) and Nofal et al. (2018) investigated the effects of PRP as a possible rejuvenating agent for reduction in infraorbital dark circles. The study was conducted as a single session of $1.5 \mathrm{~mL}$ PRP injected intradermal into the tear trough area and wrinkles of crow's feet.

\section{CONCLUSION}

Both PRP and emulsified fat were effective in treatment of infraorbital dark circles with higher rate of improvement in case of emulsified fat injection with statistically significant difference as regard the improvement, patient satisfaction and postoperative complications at end of treatment period and follow up for six months.

Conflicts of interest: No conflicts of interest were encountered.

\section{REFERENCES}

1. Alsaad SMS and Mikhail M (2013): Periocular hyperpigmentation: A review of etiology and current treatment options. JDD, 12: 154-157.

2. Al-Shami SH (2014): Treatment of periorbital hyperpigmentation using platelet-rich plasma injections. Am J Dermatol Venereol, 3(5):8794.

3. Anitua E, Alonso R, Girbau C, Aguirre JJ, Muruzabal $F$ and Orive $G$ (2012): Antibacterial effect of plasma rich in growth factors (PRGF-Endoret) against Staphylococcus aureus and Staphylococcus 
epidermidis strains. Clin Exp Dermatol, 37:652-7.

4. Mehryan P, Zartab H, Rajabi A, Pazhoohi N and Firooz A (2014): Assessment of efficacy of platelet-rich plasma (PRP) on infraorbital dark circles and crow's feet wrinkles. J Cosmet Dermatol, 13(1):72-8.

5. Nofal E, Elkot R, Nofal A, Eldesoky F, Shehata S and Sami M (2018): Evaluation of carboxytherapy and platelet-rich plasma in treatment of periorbital hyperpigmentation: A comparative clinical trial. J Cosmet Dermatol, 17(6):1000-7.

6. Oh D, Kim D, Roh T, Yun I and Kim Y (2014): Correction of Dark Coloration of the Lower Eyelid Skin with Nanofat Grafting. Archives of Aesthetic Plastic Surgery, 20(2):92.

7. Ranu H, Thng S, Goh BK, Perio, Burger A and Goh CL (2011): Periorbital hyperpigmentation in Asians: an epidemiologic study and a proposed classification DermatolSurg, 37(9):1297-1303.

8. Roberts WE (2014): Periorbital hyperpigmentation: Review of etiology, medical evaluation, and aesthetic treatment. JDD, 13: 472-482.

9. Taskin B (2015): Periocular Pigmentation: Overcoming the Difficulties. Journal of Pigmentary Disorders, 02(01): 159-174.

10. Uyulmaz S, Macedo NS, Rezaeian F, Giovanoli $P$ and Lindenblatt $N$ (2018): Nanofat Grafting for Scar Treatment and Skin Quality Improvement, Aesthetic Surgery Journal, 38(4): 421-428.

11. Zzam E, Khlosy $H$ and Abouarab M. (2020): The Efficacy of Autologous Nanofat Injection in the Treatment of Infraorbital Dark Colouration. The Egyptian Journal of Plastic and Reconstructive Surgery, 43(3):445-452. 


\section{تقييم فاعلية حقن البلازما الغنية بالصفائح الاموية مقارنة

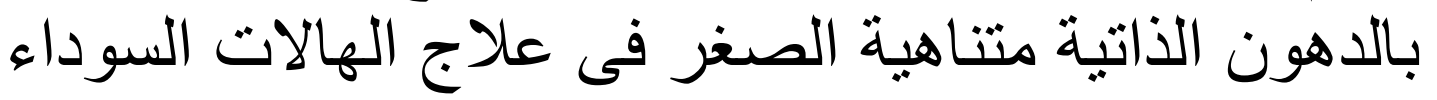 تحت العين}

أحمد قدري نبيه عطية، عبد الرعوف محمد المحسن، شادي محمود عطية

قسم الأمراض الجلدية والتناسلية وأمراض الذكورة، كلية الطب، جامعة الأزهر

E-mail: ahmedkadry420@gmail.com

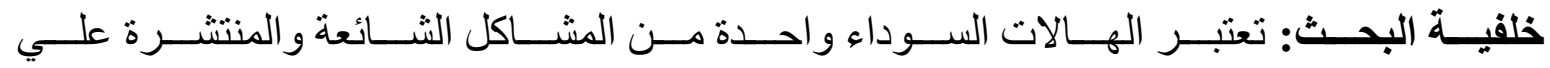

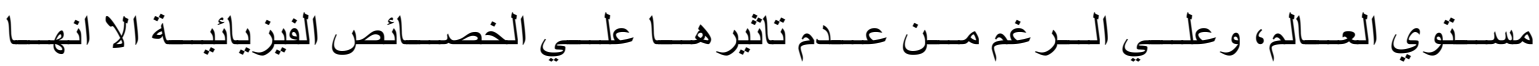

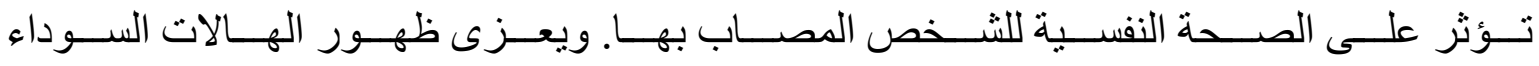

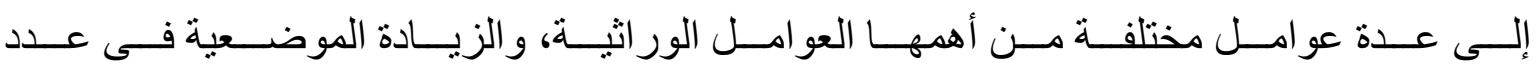

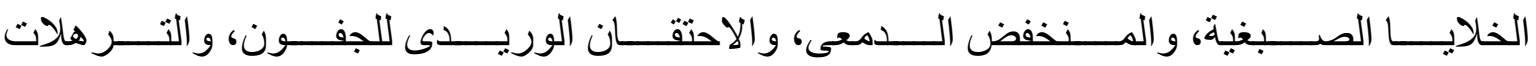

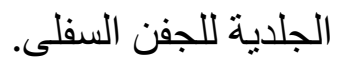

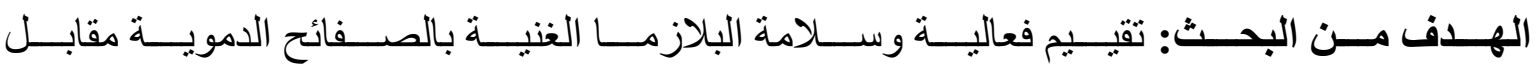
الدهون الذاتية متناهية الصغر فى علاج الهالات السوداء اسفل العين.

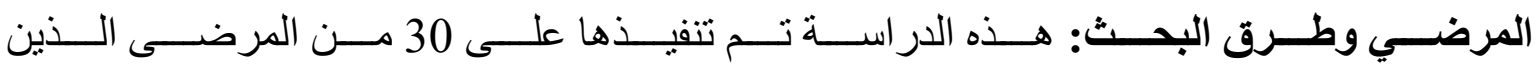

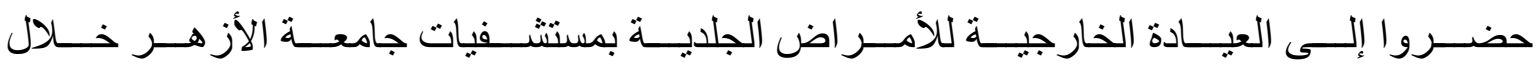

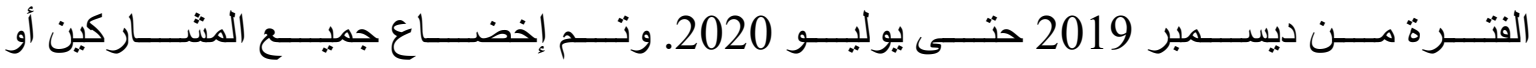

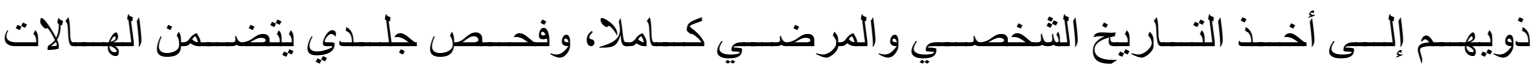
السوداء وأسبابها والثقاط الصور قبل وبعد العلاج.

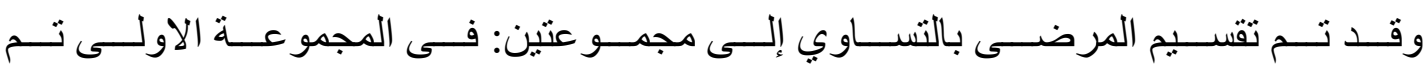

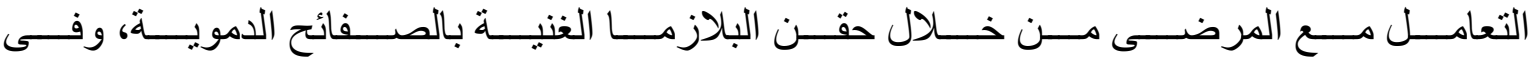

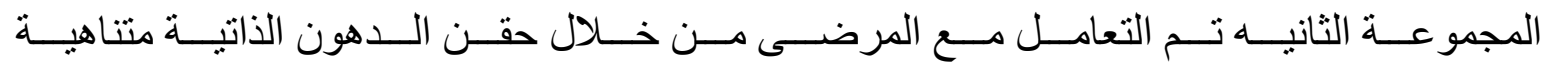
الصغر. 


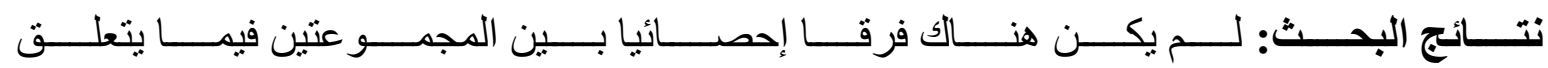

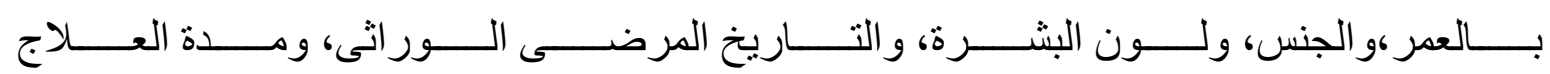
و الاستجابة للعلاج.

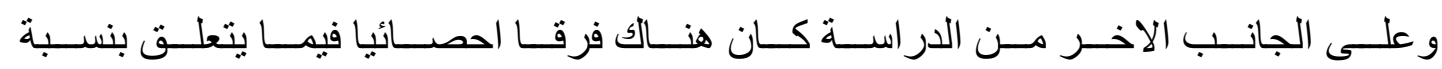

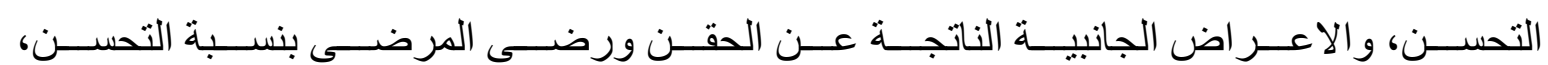

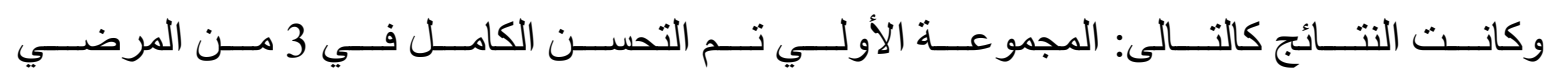

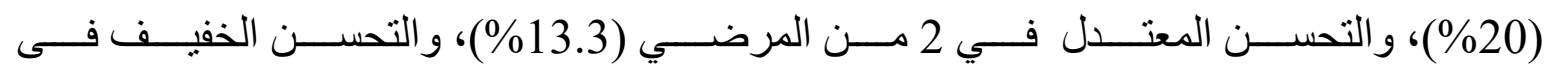

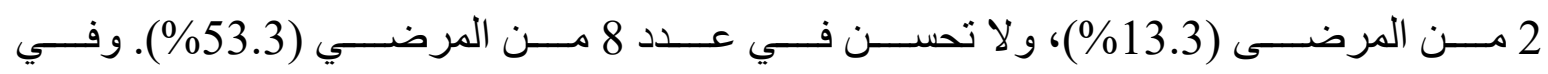

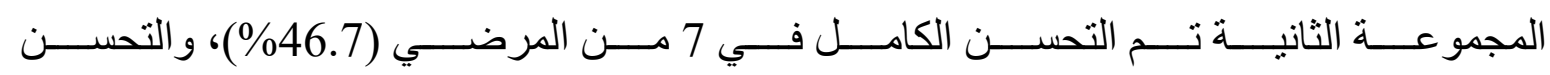

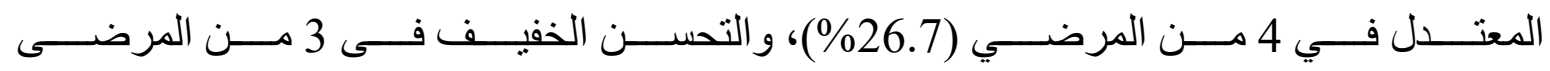
(20\%)، و لا تحسن في 1 من المرضي (6.7\%).

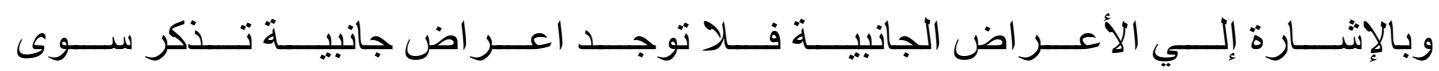

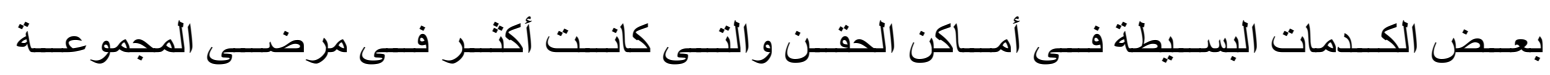

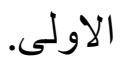

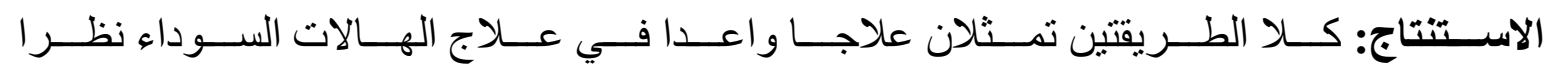

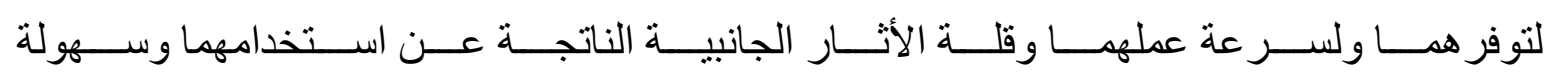

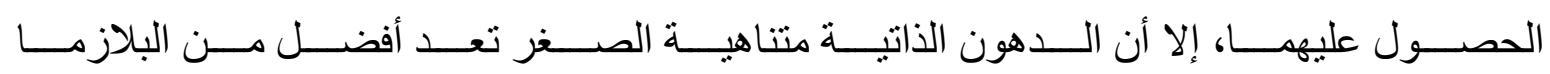

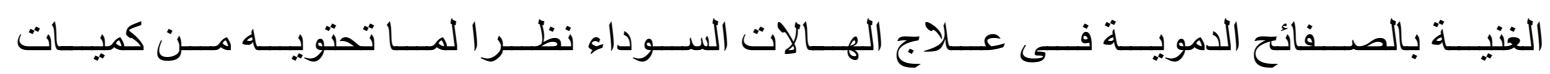

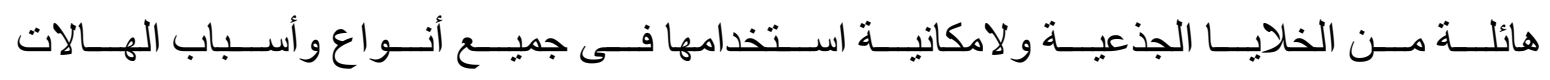

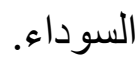

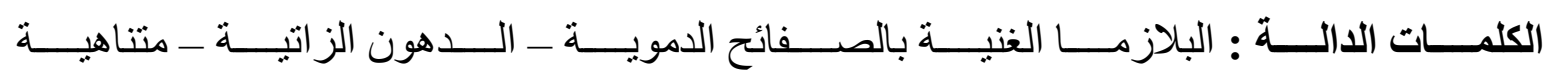

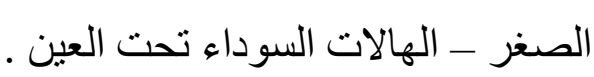

